\title{
Hardships in Mountain Livelihood: Findings from Yari Village, Humla District
}

\author{
Shiba Prasad Rijal, PhD \\ Associate Professor, Department of Geography Education \\ Tribhuvan University, Kirtipur \\ rijalshibaprasad@hotmail.com
}

\begin{abstract}
This paper aims at analyzing livelihoods of people of rural mountain areas highlighting the case of Yari village located in the north-western part of Humla district in Mid-western development region, Nepal. The study has been based on primary data collected through group discussions and key informant's interview during May 2007. As in othermountainous areas of Nepal, people of Yari village perform a number of different activities for their livelihoods. Agriculture, forest product collection, homemade production activities, hotel/catering and wage laboring are the main livelihood options and survival strategies adapted by local people. However, people's livelihood in this area is hard and insecure due to various adversities. The shortage of facilities and services, adverse climate, food deficiency, remoteness, lack of awareness, poor access to market and water stress are the main adversities faced by local people.
\end{abstract}

Key words: Assets, capabilities, diversities, hardship, livelihoods, survival strategies.

\section{The context}

Mountain region covers 37 percent of the total land area of Nepal and provides home for $1,687,859$ people according to the population census 2001 (CBS 2002). The spatial diversities in terms of landforms, micro-climates, level of development and others are wide within mountain region. The implications of these diversities can clearly be seen in local livelihoods. Mountain region, despite some opportunities, is characterized by a number of environmental adversities. People gain their livelihoods in par of these opportunities and restrictions. Owing to many adversities people in this region are living in hardship. The lowest human development index with 0.347 of this region justifies this. The average human development index of Nepal for the same period was 0.471 (UNDP 2004). The livelihood condition of people of Mid-western region especially of rural and isolated settlements is associated with widespread poverty and disparity.

People in rural mountains, as in other areas, perform often several activities to eke out wide variety of their needs. They pursue livelihood strategies based on the combination of assets they own and opportunities and restrictions created by the environment (Pain and Lautze 2002). 
It depends on how people organize to transform environment to meet their needs through technology, labor, power, knowledge and social relations (Hoeck 2001). Access to assets has probably the major influence on choice of livelihood strategies (Chambers and Conway 1991; Scoones 1998; DFID 1999). However, the capabilities of people exploiting assets and the nature of the environment cannot be undermined (Pain and Lautze 2002). Castes and cultural practices also have influence on livelihoods.

Enormous diversities in livelihoods are realized by locality (Bishop 1990, Zoomers 1999, Dahal 2001, Subedi and Pandey 2002, Sulivan et al. 2004, Rijal 2006 and 2007) across sectors and households. Many choices and options are normally open to the people; the actual livelihood is determined by the peoples' evaluation of the possibilities offered by the environment (Knowled and Wareing 1996). In this context, the present study is aimed at analyzing livelihoods of rural mountain focusing on Yari village of Humla district in Mid-western Development Region, Nepal. Mountain region in western Nepal exhibits diversities by locality in terms of opportunities and restrictions created by local environment as well as manmade factors. Such diversities may have direct and indirect implications in shaping people's livelihoods. Yari village in mountain region is an isolated settlement which may have both diversities and similarities to the other areas. Thus, understanding livelihoods of an isolated locality in micro level is of great significance to identify the diversities in livelihood pattern within mountain region.

\section{Study area and methods}

Yari village is located in the north-western corner of Humla district near Nepal-China boarder of Nepal (Figure 1). This is an isolated village located at about three-days walking distance from the district headquarters, Simikot. Hilsa Simikot-trail passes through this village. Yari village consists of two settlements, viz. Yari and Gumba Yari. Both settlements in this village are situated at an altitude of about 2800 meters from the mean sea level within a distance of half kilometers. This village experiences cool temperate climate with short and mild summer and relatively long and cold winter.

Figure 1: Location of Study Area

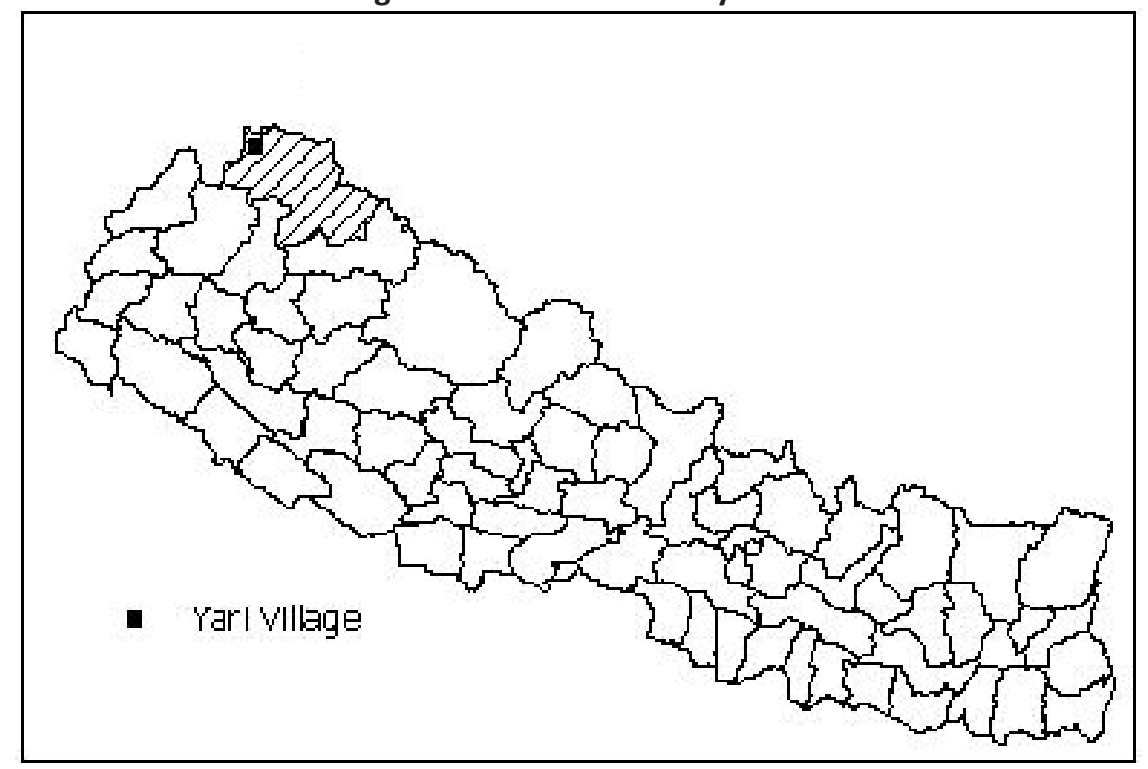


There are altogether 27 households in the study area comprising 19 households of Yari and 8 of Gumba Yari. Total population of these two settlements was 150 persons (110 persons in Yari and 40 persons in Gumba Yari) in 2007, consisting almost equal proportion of male and female. The average family size was 5.6 persons. Both the settlements are resided by Tamang community of Tibetan origin. They called themselves as Lama and belong to Buddhist religion. The polyandry system is common in this society.

The study is of descriptive cum analytical type and primarily based on primary data and information. The primary data was collected through group discussions and key informant's interview during May 2007. Relevant secondary data were obtained from published documents and official records.

\section{Livelihood options}

People of this area perform a number of different activities for their livelihood. These include agriculture (both crop and livestock farming), forest product collection, homemade production activities, hotel/catering and wage laboring. A diverse portfolio of activities contributed to the sustainability of rural livelihoods (Ellis-Jones 1999). A brief account of livelihood activities adopted for their livelihood security is discussed below.

\section{Agriculture}

People of this village primarily rely on agriculture for their livelihoods. Agriculture in this area is of subsistence type characterized by both crop farming and livestock. Nafal (a type of wheat grown in higher altitude), oil seed, buckwheat and potato are the main crops, whereas turnip, cabbage and spinach are the main vegetables grown in this area. People use local seeds, manure and traditional implements in farming. Only one harvest is possible in a year from a plot owing to cold climate associated with high altitude. Prolonged growing season and traditional methods of farming result in low per unit production. As a result, this village is not self sufficient in food production. Irrigation facility is available in the village; however, frequent obstruction of irrigation canal by landslide heavily disrupts irrigation and ultimately production of crops, since irrigation canal passes through long landslide prone areas.

Rearing livestock is an integral part of agriculture along with crop farming in this village. It is one of the income sources too. Yak, Chauri, jhopa/jhuma, sheep and horse are the main ruminants reared by the households. All households possess livestock but their number varies from one household to another. The number of livestock ranges from 5 to 30 heads and all of them are local ones. Large number of livestock is the sign of well-being of this settlement. Transhumance activities are commonly practiced. However, they keep some animals at home which they use for draught power for ploughing agricultural fields and transporting goods to and from markets. During summer they move their herds to the pastures of higher altitudes and in the winter they return to the lower altitudes. During the course they keep their herds at their home twice a year. The contribution of livestock to local livelihood is significant. People use animal products for both household consumption and sale. They sell animal products like wool, live animal and skin and use earned income to fulfill household needs. People use animal dung for crop production. 


\section{Forest product collection and sale}

Forest is one of the major livelihood bases of people living in Yari village. Collection of forest products is one of the survival strategies of the locals as they collect timber, firewood, leaf/litter, fodder, herbs, mushroom, and green vegetables from the forest. They collect forest products especially timber, leaf of $d$ hupi and herbs for business purpose. All the households collect forest products; however the volume varies depending on family size, number of livestock heads and others. Collection of timber is estimated to range from 100 to 300 cubic feet with an average of 180 cubic feet per household per year. Likewise, a household collects 1 doko leaf/litter, 2 bhari fodder and 1 bhari firewood per day. However, the collection of fodder and leaf/litter limited to only about 6 months because of transhumance practice.

Exporting timber is the main source of cash income of the local people. People collect timber from nearby forests and sell to the Tibetan market in Sera at high price. Export business starts from second week of June and runs up to the October till closing the high pass (Nara Lekh) to the market by snowfall. On an average household earned about Rs 50,000 per annum from selling the logs. A piece of log measuring 8 feet long ( 4 inch thick and 4 inch wide) costs Rs 250 at Sera market of Chinese border. Transportation of logs/timber and other consumable household goods depend completely on draught power. They use yak, jhopa (mail cross-bread from yak and local cow) and horse for this work.

The annual income of the household from log business is grouped into four categories ranging from less than Rs 30,000 to above 50,000 (Table 1). The proportion of households earning more than Rs 50,000 is about one-fifth. More than one-third of the households earned less than Rs 30,000 annually.

Table1: Annual household earning selling logs

\begin{tabular}{lc}
\hline Income (Rs) & Percent of households \\
\hline Less than 30,000 & 37.0 \\
$30,000-40,000$ & 22.2 \\
$40,000-50,000$ & 22.2 \\
Above 50,00 & 18.6 \\
\hline
\end{tabular}

Source: Field survey, 2007

The forest area nearby settlement has declined sharply due to over exploitation. As a result timber business is being less profitable in recent years. However; people are continuing the same business with more time and effort since they do not have better alternatives for cash income. Along with logs, local people collect herbs, firewood, fodder and leaf/litter from forest. They also sell herbs and mushroom at the Chinese market. They also collect green vegetables from forest. Over exploitation of forest products especially timber has caused a serious threat to this area as environment is deteriorating rapidly. No tree left suitable for timber/log is available nearby the settlement and no forest conservation program is launched.

\section{Hotel/Catering}

Involvement in hotel and catering activity is also one of the livelihood options adopted by the local people. A remarkable proportion (about 25 percent) of households of this area is involved 
in this sector. There were half a dozen hotels cum tea stalls in operation along the Hilsa-Yari under construction road near the main settlement in Yari village. Food, tea and snacks and liquor are the main food items available in these stalls. This is a seasonal business operated during tourist season from May to November. During this time tourists from Simikot visit Hilsa. Especially tourists to Mansarober Lake pass through this way. Tea stalls remain closed from December to April due to cold climatic condition. This sector provides both part-time employment as well as cash income to the locals.

\section{Homemade production activities}

Local people are also involved in forest-based production activities. They produce incense sticks at their home collecting leaf of dhoopi tree from the forest. Making incense stick is not only the source of income; it provides part-time employment too. Almost all household members especially female are involved in this activity. They sell incense stick either in cash or in exchange of the foods at both Chinese and Nepalese markets. Price of incense stick at Chinese market was Rs 35 per kg. The average household earning from this activity was estimated to be Rs. 10,000 . They also produced juice from Dalechuk/Tarchuk locally and sell to both Chinese and Nepalese markets. There is a good possibility of Dalechuk processing as there are plenty of raw materials in the nearby forest. Establishment of Dalechuk processing plant will help local people by providing employment opportunity and enhancing income level.

\section{Wage labor}

Working for wage is another option and survival strategy adopted by local people. Since Hilsa-Simikot road is under construction, the demand of both skilled and unskilled labor force is high in this area. Owing to location in high altitude, the construction work in this area is seasonal. People become engaged in road construction work during summer as construction work remains closed during winter due to cold climate and snowfall. Both male and female of working age from all households get involved in road construction work. They get wage ranging from Rs 200 to 350 per day per person depending on types of work. Workers receive both cash and kind. Since World Food Program is one of the donor agencies of that program, it provides food grains for construction workers under 'Food for Work' scheme. Beside road construction, people especially poor ones get involved in agricultural works too for wage. They use earned income to fulfill their household needs.

\section{Adversities in livelihood}

Livelihood of Yari people is hard and insecure owing to various adversities. These include adverse physical environment, shortage of facilities and services, shortage of food, limited employment opportunities, water stress and others. A brief account of major adversities of people's livelihoods of this area is discussed below:

\section{Physical environment}

Located in high altitude, this area is characterized by prolonged cold climate with short mild summer. Temperature drops below freezing point during winter and covers village by snow/ ice almost for four months during snowy season. People remain economically inactive from November to the March and spend time sitting beside fire inside home. After March people 
become involved in gainful economic activities till November. Environment within and outside home is unhealthy and unpleasant. Houses are congested with poor ventilation and smelled bad since they keep livestock in the ground floor of the same house. The open defecation and poor sanitation are also common in the village.

\section{Food deficiency}

Agriculture is the main stay of livelihoods of this area; however local production is not sufficient for household food requirements. More than 92 percent households do not produce sufficient food for their household's annual requirements. They suffer from food deficiency for 3 to 9 months per year. Out of total 27 households, only two households produced enough foods for the household consumption (Table 2). Similar scenario of mountain food situation for Nepal was showed by Jenny and Egal (2002). Adverse environmental condition and traditional agricultural practices are responsible for this low food production. In addition, food habit is equally responsible for food deficiency. Since people of this village belong to Tamang community, they celebrate varieties of cultural and religious festivals and ceremonies for which they use large amount of liquors. For this, they use large amount of their agricultural production for making liquors which results in food shortage.

Table 2: Household's food sufficiency status

\begin{tabular}{lcr}
\hline Status & No. of households & Percentage \\
\hline Year round & 2 & 7.4 \\
6 to 9 months & 12 & 44.4 \\
Less than 6 & 13 & 48.2 \\
Total & 27 & 100.0 \\
\hline
\end{tabular}

Source: Field survey, 2007

People of this village have adapted a number of food deficit management practices in order to protect themselves from food deficiency. They either managed their food deficiency through purchasing foods from Chinese market with their own income out of selling timber or earning grains through wage labour. They also managed food deficiency exchanging food items to their local industrial productions like incense sticks, dalechuk and animal products.

\section{Water stress}

Piped drinking water facility is available in the settlement. Since individual taps are not distributed, people fetch water from public taps. Water is available throughout the day from these taps during summer. But water stress becomes crucial during winter season. Due to location at higher altitude, source of drinking water freezes during winter and people have to travel long distance to the river that flows below the settlement to fetch water for household consumption. They have to walk about 3 kilometers of distance to fetch water from nearest river. Fetching water becomes time consuming and difficult due to sleepy trails as caused by thawing and freezing action during day and night. It takes more than an hour for a trip to fetch water. People need much water during winter since some of livestock as mentioned above in this season are put to stall feeding. 


\section{Shortage of facilities and services}

Remoteness in Nepal is associated with widespread poverty and disparity (Upreti and Boker 2010). Yari is a remote village and people are living in isolation and out of reach from modern facilities and services. This village is not connected by roads and transportation depends completely on traditional modes i.e. animal (yak, jhopa and horse) and people. As noted above, the under constructed Hilsa-Simikot road track passes through this village, the track of HilsaYari section is recently opened. However, the track remains closed during winter due to snow cover as road passes through altitude more than $\mathbf{4 0 0 0}$ meters from Nara Lekh. People have to walk three days to reach district headquarters i.e. Simikot. This village does not have electricity. People use pine wood for lighting, making house warm and cooking that makes lots of smokes in the house. Smokes make poorly ventilated houses untidy and unhygienic to live.

High incidence of diseases due to harsh weather conditions, poor hygiene combined with poor curative and preventive health services is common in mountain areas (Jenny and Egal 2002). The condition of Yari village is not different. Smokey kitchen, poor sanitation within and around house and lack of health service result in health problems among the local people. Common cold, eye irritation as well as stomach problems are common health problems faced by locals. No health facility is available within and nearby community. People either depend on local Amchi (traditional health worker) for treatment or on super natural power of god.

People do not have access to telephone and internet facilities. Likewise, they do not have access to newspapers and television. Banking facility is not available within and nearby village. They have to depend on local moneylenders for cash at high interest rate. As a result, households of this village are characterized by poor human capitals.

\section{Market and other problems}

Since Simikot is the only market within Nepal within about three-days walking distance, people of Yari village depend largely on nearby Chinese market which can be reached by a day-long walking. This market also remains closed due to thick winter snow over the trail at Nara Lekh. People have to face the shortage of consumable goods in case they do not manage the required items before the trail is closed in winter or they have to spend more time and effort travelling distant market of Simikot bazaar.

In addition, people of this village suffer from other adversities too. Destruction of crops by wild lives and livestock are common. Since village is isolated and covered by grassland and forest by all sides, the possibility of destruction of crops by wildlife is high. Rats, beer and porcupine heavily destroy crops before harvesting.

\section{Conclusions}

People of western mountain Nepal are living in hardship. The condition of Yari village is even harder and insecure as caused by varieties of adversities. The shortage of facilities and services, limited employment opportunities, unhygienic environmental conditions within and outside home, food deficiency, remoteness, poor access to market and water stress are the main adversities causing livelihoods hard and insecure. 
People of this village have adopted several livelihood activities as survival strategies. Though agriculture is a major livelihood base, majority of the households (92 percent) do not produce sufficient food to meet their food requirements and suffer from food deficiency ranging from few months to three-quarters of a year. Food habit and traditional agricultural practices are responsible for this. Improving these practices may help in securing better livelihood condition.

Local environment is getting deteriorated due to over exploitation and rampant destruction of forest for timber. The deterioration of environment may have serious effect on sustainability of livelihoods. Provision of facilities and services will help for better livelihoods of the people by improving the state of human capital. Likewise, awareness programs would be proved useful for sustainable use of forest.

\section{References}

Bishop, B. C. (1990), Karnali under stress: livelihood strategies and seasonal rhythms in a changing Nepal Himalaya. Illinois: University of Chicago.

Central Bureau of Statistics (2002), Population census 2001: national report. Kathmandu: CBS.

Chambers, R. and Conway, G. R. (1991), Sustainable rural livelihoods: practical concepts for the $21^{\text {st }}$ century (Discussion Paper 296). Brigton: Institute of Development Studies (IDS).

Dahal, K. B. (2001), "Struggling with development: a case study of the changing livelihood strategies of the Baramus from western Nepal". Unpublished Master's thesis in Sociology/Anthropology: Tribhuvan University.

Department for International Development (1999), Sustainable livelihoods guidance sheets. London: DFID.

Ellis-Jones, J. (1999), Poverty, land care, and sustainable livelihoods in Hillside and Mountain regions. Mountain Research and Development, 19 (3): 179-190.

Hoeck, W. van der. (2001), Water and rural livelihoods. Retrieved from http://www.ifpri. org/2020/focus09/ focus09_05.htm.

Jenney, A. L. and Egal, F. (2002), Household food security and nutrition in mountain areas: an often forgotten story. Retrieved from http://www.mountainpartnership.org/files/pdf/ factsheets/nutrition-en.pdf

Knowled, R. and Wareing, J. (1996), Economic and social geography. New Delhi: Rupa \& Co.

Pain, A. and Lautze, S. (2002), Addressing livelihoods in Afghanistan. Kabul: Afghanistan Research and Evaluation Unit.

Rijal, S. P. (2006), "Water and livelihoods in mountain areas: a case of Modi watershed, Nepal". Unpublished doctoral dissertation: Tribhuvan University.

(2007), Land Holding and Livelihoods: A synthesis from Modi Khola Watershed, Nepal, The Third Pole, 5-7: 43-51. 
Hardships in Mountain Livelihood: Findings from Yari Village, Humla District - Shiba Prasad Rijal

Scoones, I. (1998), Sustainable rural livelihoods: a framework for analysis (Working paper 72). Brigton: Institute of Development Studies.

Subedi, B. P. and Pandey, R. (2002), Livelihood strategies of Rai communities in Arun valley: Continuity and change. In Chaudhary, R. P, Subedi, B. P Vetaas, O. R and Aase, T. H. editors, Vegetation and society: their interaction in the Himalayas. Kathmandu: Tribhuvan University, Nepal and University of Bergen, Norway.

Sulivan, C. A., Rijal, S. P., Shrestha, M., Khanal, N. and O'regan, D. P. (2004), An assessment of the potential impacts of climate-induced deglaciation on communities and their livelihoods in the Hindu Kush-Himalaya. (DFID KAR Project No. R7980). Wallingford: Center for Ecology and Hydrology.

UNDP. (2004), Nepal human development report 2004: empowerment and poverty reduction. Kathmandu: UNDP.

Upreti, B. R. and Müller, B., editors, (2010), Livelihood insecurity and social conflict in Nepal. Kathmandu: Swiss National Centre of Competence in Research (NCCR) North-South

Zoomers, A. (1999), Linking livelihood strategies to development: experiences from the Bolivian Andes. Amsterdam: Royal Tropical Institute. 